\title{
THE EFFECTS OF THE AUTHORITARIAN PARENTING TOWARD STRESS AND SELF-ESTEEM OF TEENS
}

\author{
Dwi Rahmah Fitriani ${ }^{1}$
}

${ }^{1}$ Department of Nursing, Faculty of Health and Pharmacy, Universitas Muhammadiyah

Kalimantan Timur

Corresponding Author : drf397@umkt.ac.id

\begin{abstract}
Adolescence is a period of development and a period of adjustment for adult life and a period of stress and stress is a time of turmoil and pressure. At this time, there was a shift in the role of peers who began to "shift" the role of parents. Parents have an impact on adolescent development through the application of authoritarian parenting that is rigid and strict when interacting with adolescents and not infrequently can create tension in the relation of adolescents with parents so that it can provide psychological effects indirectly. Purpose of the study: This study aimed to determine the relation of authoritarian parenting parents with stress levels and adolescent self-esteem. Research methods:: The method used in this study is a correlation with independent variables parenting and self-dependent variable in adolescents. The population in this study were adolescents in vocational high school as many as 218 respondents with a total sample of 141 respondents taken by stratified random sampling technique. The instrument in this study used the Depression Anxiety Stress Scale questionnaire and Rosenberg Self Esteem and for authoritarian parenting, the writer modified the questionnaire then validity test was conducted. The data was then analyzed using the Spearman correlation test. Results: Showing that authoritarian parenting parents with stress levels have a relation with the results of the spearman correlation test $\mathrm{rs}=0.002$ and for authoritarian parenting parents and self-esteem there is no relation with the results of the Spearman rho correlation test $=0.139$. Conclusion: There is a correlation between the authoritarian parenting style of parents and stress levels can be interpreted that parents who apply the type of authoritarian parenting to their teenagers tend to experience stress from mild to severe. There is no relation between parental parenting and adolescent self-esteem. Can be interpreted that the application of authoritarian parenting from parents in adolescents is not related to adolescent self-esteem. Suggestion: Provide positive support to adolescents to prevent adolescents from experiencing stress, and not limit every activity that teens like so that teens can socialize with their environment.
\end{abstract}

Keywords: Authoritarian parenting, Stress Levels, Self-Esteem and Adolescence.

\section{PRELIMINARY}

Teenagers in Latin are called "adolescence" which means growing or growing up. The term adolescent has a meaning that includes enough emotional, mental, social and physical maturity, where adolescence is included in the transition period in the span of human life that connects childhood and adulthood ${ }^{1}$. Adolescence is a period of development and adjustment period for adult life. Most of the time, adolescents are ignored, stereotyped, and misjudged based on their nature and age ${ }^{2}$. Adolescents need to be prepared mentally as early as possible so that they are expected to be able to solve the problems they are facing such as obstacles, difficulties, constraints and deviations of life including social life in accordance with development ${ }^{3}$. 
Adolescents prefer their self-image to be different from others, but in reality adolescents often feel dissatisfied with their circumstances, so adolescents grow into individuals who are aware of themselves and make an assessment of themselves. Adolescence begins to form and has a more accurate self-concept than previous periods ${ }^{4}$. Self-esteem is a self-evaluation made by each individual who shows a person's attitude towards himself, ranging from the very negative to the very positive ${ }^{5}$. Someone who has positive self-esteem can be interpreted that a person likes himself, evaluating this positive self-esteem based on the opinions of others and as based on specific experiences. Whereas individuals who have negative self-esteem will feel that they are useless, worthless and always blame themselves for their imperfections, they tend to lack confidence in carrying out all tasks and do not feel confident about the ideas they have.

Adolescence is a period of stress \& stress is a time of turmoil and pressure. During this period a shift in the role of peers began to "shift" the role of parents as a reference group which not infrequently also created tension in adolescent and parent relations ${ }^{2}$. Parent and teen relation can be a source of stress and depression in adolescents if parents are too hard in educating children. Self-esteem in early adolescents is predicted to be depressive symptoms in late adolescence and early adulthood. Both of these psychological stresses will adversely affect intellectual abilities, emotional development and physical changes that begin with stress ${ }^{6}$.

Stress is an individual response to circumstances and events that trigger stress (stressors), which threaten and interfere with one's ability to handle it (coping). Stress occurs due to various demands that can produce stress in adolescents' lives such as schoolwork and overwork, feeling frustrated, unpleasant family conditions or living with poverty can also produce stress. Middle school adolescents in Delhi were $87.6 \%$ positive experiencing stress where academic pressure was one of the main precursors to stress, $70 \%$ exams had contributed to much stress, followed by 3 friends, $0 \%$, parents $11.8 \%$, teachers $6.3 \%$ and other factors $49.7 \%{ }^{7}$.

Parents' high expectations and academic achievement scores of adolescents are both positively related to depression. Self-efficacy, the frequency of parental support, the frequency of school support, and academic performance are all negatively related to depression. This shows that parental support is demonstrated by the way parenting parents can make teens make decisions. Teenagers will experience a change from being dependent on parents to be independent and more responsible to themselves ${ }^{8}$.

Authoritarian or authoritarian parenting applied by parents to their children who are rigid and strict when interacting with children by applying the rules they make without many questions and explanations why their children are about the reasons why these regulations are enforced $^{9}$. Several studies have shown that authoritarian parenting always has a negative effect on self-esteem; it destroys adolescent self-confidence and increases insecurity ${ }^{10}$. This parenting causes fear that affects the child's development, causes the child's creativity not to develop, the child becomes timid, nervous when in the community and apathetic. 
Parents who apply authoritarian parenting to adolescents will form the attitude of adolescents to be timid, anxious and closed and adolescents who are cared for with this type of parenting are more easily influenced to do things that are likely to have a negative impact ${ }^{11}$. This shows that parenting is one of the factors that makes teenagers able to socialize with their environment so that they can determine their mental development in the future as an adult who will enter the task of further life development.

Based on the results of the preliminary study of researchers by interviewing 28 vocational high school students directly, ten students said that having parents who rarely communicated, did not give children the opportunity to argue and physically punish children. 10 students said they felt pressured by the current situation that caused a loss of interest in doing activities at school and at home and there were 8 students who had low self-esteem. The students said they felt inferior and said they were not satisfied with themselves. Based on this background with the phenomenon that there are symptoms of stress and a picture of self-esteem in adolescents, the researcher is interested in taking the title about the relation between parental authoritarian parenting with stress levels and adolescent self-esteem in Vocational High School students.

\section{MATERIAL AND METHOD}

This research uses a quantitative approach using descriptive correlative research methods with a cross-sectional research design. The population of this research is class XI students in marketing and social care majors who are in Samarinda vocational high school, totalling 218 students by selecting samples taken and determined by stratified random sampling technique as many as 141 students.

The instrument used in this study was authoritarian parenting that was developed by the researcher with 22 question items that were vailed with a value of $r=0.404-0.792$ and a reliability test using Alpha Cronbach from the parenting variable obtained a value of 0.744 . As for the stress level, the Depression Anxiety Stress Scale instrument is used and for self-esteem, the Rosenberg Self Esteem Scale instrument is used. The analysis test uses the Spearman rho correlation test with sig $\leq 0.05$.

\section{RESULT AND DISCUSSION}

1. Univariate Analysis

a. Characteristics of Respondents 
Table 1

Characteristics of Respondents $(n=141)$

\begin{tabular}{ccc}
\hline Characteristics of Respondents & $\begin{array}{c}\text { Frequenc } \\
\mathrm{y}\end{array}$ & Percentage (\%) \\
\hline Age & 15 & \\
15 & 73 & 10,6 \\
16 & 46 & 51,8 \\
17 & 6 & 32,6 \\
18 & 1 & 4,3 \\
19 & & 7 \\
\hline Gender & 73 & 51,8 \\
Female & 68 & 48,2 \\
Male &
\end{tabular}

Source: Primary Data

The results showed that the age of the respondents from 141 respondents was mostly 17 years old as many as 46 people (32.6\%) and the oldest was 19 years old there was one person $(7 \%)$. While female respondents numbered 73 (51.8\%) and men amounted to 68 people (48.2\%).

a. Characteristics of respondents based on authoritarian parenting variables, stress and self-esteem

Table 2

Respondent characteristics based on authoritarian parenting, stress and self-esteem $(n=141)$

\begin{tabular}{ccccc}
\hline Variable & $\mathrm{N}$ & $\begin{array}{c}\text { Media } \\
\mathrm{n}\end{array}$ & $\begin{array}{c}\text { Elementary } \\
\text { school }\end{array}$ & Min-Max \\
\hline $\begin{array}{c}\text { Authorita } \\
\text { rian }\end{array}$ & 141 & 34,0 & 5.89 & $33.42-$ \\
Parenting & & & & 35.38 \\
\hline Stress & 141 & 30,0 & 6.91 & $28.88-$ \\
Level & & & & 31.19 \\
\hline Self- & 141 & 29,0 & 3.23 & $28.51-$
\end{tabular}

The results Esteem 29.59 of the study found that the authoritarian parenting median was 34.0, with SD 5.89 and the lowest value was 33.42 and the highest was 35.38. The stress level is a median value of 30.0 with SD 6.91 and the lowest value is 28.88 and the highest is 31.19 and self-esteem is a median value of 29.0 with SD 3.23 and the lowest value is 28.51 and the highest is 29.59. Analysis Bivariate 
Table 3

The relation between authoritarian parenting with stress levels and adolescent self-esteem.

\begin{tabular}{ccc}
\hline Variable & \multicolumn{2}{c}{ Authoritarian Parenting } \\
\cline { 2 - 3 } & $\mathrm{R}(\mathrm{s})$ & $\mathrm{P}$ Value \\
\hline Stress level & $0,259^{* *}$ & 0,002 \\
& & 0,139
\end{tabular}

Based on the table above it can be seen that for the authoritarian parenting variable and stress level obtained P-value $=0.002 \leq 0.05$, so that Ho is rejected Ha1 is accepted, which means there is a relation between authoritarian parenting with stress level. The value of $\mathrm{R}$ (s) obtained 0.259 ** has a weak correlation strength with a directional or positive direction of correlation, meaning that the more often parents use authoritarian parenting, the higher the value of stress levels in adolescents.

Variable authoritarian parenting with adolescent self-esteem obtained P-Value $=0.139>0.05$, so that Ho is accepted and $\mathrm{Ha}$ is rejected, which means there is no relation between parental authoritarian parenting with self-esteem in adolescents. The value of $\mathrm{R}$ (s) obtained -0.125 which has a low interpretation with the direction of a negative relation, meaning that the more often parents apply parental authoritarian parenting, the lower the self-esteem of adolescents.

The results showed that the age of respondents from 141 students mostly aged 17 years as many as 46 people (32.6\%) and the oldest aged 19 years there was 1 person (7\%). While female respondents numbered $73(51.8 \%)$ and men amounted to 68 people $(48.2 \%)$.

Teenagers are called in Latin adolescence, which means "growing up" or "growing up". The term adolescent has a broader meaning including emotional, mental, social and physical maturity, where adolescence is a transition period in the span of human life that connects childhood and adulthood ${ }^{1}$. Comparisons in adolescents aged 11-18 years where the age of 16-18 years by $51.1 \%$ who use and do not use substances, smoke, and drinking, have a background in smoking behaviour of family members where adolescents who have fathers smoking by $44.6 \%$ and having friends who smoke by $22.9 \%{ }^{12}$. This shows that the environment plays an important role in the change and development of adolescent behaviour in carrying out their lives.

The sex of respondents, mostly female was $73(51.8 \%)$ and male was 68 (48.2\%). The role of sex is part of a social role and cannot be determined by the gender of the person concerned but by the environment and other factors ${ }^{3}$. Research in 48 countries found an increase in age-related self-esteem from late teens to middle adulthood with men consistently showing higher self-esteem than women ${ }^{13}$. This is not in line with the study. Cultural differences have a bearing on the development of self-esteem in men and women. The relation between personal self-concept and overall self-concept of adolescent boys having a good and positive self-concept than adolescent girls, but physical self-concept and overall self-concept, as well as social self- 
concept and self-concept as a whole ${ }^{14}$. Overall, higher in adolescent girls than adolescent boys. This shows that gender plays a major role in the formation of adolescent self-esteem so that it needs support from parents to be able to help shape adolescent self-esteem so that it develops positively.

The results of authoritarian parenting research with a median value of 34.0 with SD 5.89 and the lowest score of 33.42 and the highest of 35.38 obtained authoritarian parenting. This shows that 141 Samarinda vocational high school students mostly get authoritarian parenting from parents. Parents who practice authoritarian parenting is $23.4 \%$, authoritative $26.9 \%$, indulgent $23.1 \%$ and neglectful by $26.6 \%{ }^{15}$. Authoritarian parenting is felt by adolescents because adolescents often get physical punishment as a form of consequence that must be received by children when violating rules or standards set by parents for their children. Children also consider that home is a place where children must comply with parental standards.

Based on the results of the study it can be seen that the stress level of the median value is 30.0 with SD 6.91 and the lowest value is 28.88 and the highest is 31.19 , it shows that respondents tend to experience severe stress. Adolescents who experience severe stress are caused by processes that interpret something bad, in the form of responses that are always used negative and there are indications that interfere with self-integrity so that it can be interpreted as a threat and become distressed. Research results stress is one of the important factors that affect students' ability to deal with their problems and can interfere with studies, this happens because of a tense situation that affects emotions, cognition and student conditions ${ }^{14}$. High levels of stress will affect the ability of students to deal with problems at the age of development in the range of adolescent testing.

Adolescent development is characterized by significant neurological, cognitive and sociopsychological development. With the advancement in adolescence, the amount of time spent with parents usually decreases, whereas much teenage time is spent with peers. Nevertheless, parents continue to play a key role in influencing the development of their teenagers. The parental attachment has a profound effect on cognitive, social and emotional functioning resulting in decreased mental health problems, and increased social skills and coping strategies. Parental care can reduce adolescent psychological problems, including decreased antisocial behaviour, stress and drug use.

Teenagers are periods marked by anxiety, doubts, questions, doubts, etc. Rapid changes that occur during adolescence and feelings of self-consistency do the search for identity more prominent during adolescence. The main task of adolescents is to find and build identity. The formation of identity is very dependent on society, its values and the people who interact with it. This search for identity is very important in adolescence and this is achieved through identification with different individuals such as parents, peers, teachers, heroes so that the role of friends in the formation of identity is also very important. The results of his study of 300 adolescents showed that the source of stress in adolescents was influenced by themselves, 
parents and peers ${ }^{16}$. Most students namely $63.5 \%$ feel stressed due to academic pressure and there are $66.0 \%$ of students reporting that their parents are pressuring them for more academic achievement well. The level of parental pressure experienced differed significantly across levels of parental education, mother's occupation, number of private teachers, and academic achievement.

The results showed the characteristics of self-esteem showed that of 141 respondents, self-esteem had a median value of 29.0 with SD 3.23 and the lowest value of 28.51 and the highest of 29.59. This shows that the average teenager has high self-esteem, even though there are also teenagers who have low self-esteem. Low self-esteem in adolescents who are constantly associated with serious psychological difficulties (depression; anxiety disorders such as social phobia, bulimia and self-abuse), adolescents do not want to develop, shy in the class or in the community environment due to bad from other low self-esteem is suicide, suicide cases in adolescents often occur because they experience a very deep feeling of shame that causes loss of self-esteem and becomes depressed ${ }^{17,18,19}$.

Researchers argue that respondents or students who become respondents have normal self-esteem and there are also those who have high self-esteem, from the total scoring results from the Rosenberg self-esteem scale questionnaire found no respondents or students who have low self-esteem. Individuals who have normal to high self-esteem have a good attitude of selfacceptance have a positive picture about themselves, can manage frustration and anger, can interact and accept criticism from others, can regulate emotional states. Someone who has high self-esteem will feel not dependent on others; individuals are able to accept failure and defend themselves if they get negative feedback from others, and protect themselves from the negative evaluation of their social groups.

Statistical test results to test the relation of parental authoritarian parenting with stress levels in adolescents using the Spearman rho correlation obtained P-Value $=0.002$ which is smaller than $\alpha 0.05$ so that Ho is rejected and Ha is accepted which means that there is a relation between authoritarian parenting parents with stress levels. With a value of $\mathrm{R}(\mathrm{s})=0.259$ it means that the strength of the correlation is weak with a positive or unidirectional direction that is the more often the parents apply authoritarian parenting to the child, the higher the stress experienced by the child.

Based on the researchers' assumptions on this stress level variable, it is found that parenting attitudes or patterns play an important role during adolescence like this, if parents apply parental care that is not right for their children it will result in children who will easily experience stress disorders, in addition to patterns foster support from parents and the environment around adolescents is needed right in adolescence so that adolescents get the right coping stress and do not end in mental disorders due to lack of support from the surrounding environment and lack of adolescents in the process of coping with stress correctly. In line with research conducted on ASU patterns. 


\section{CONCLUSION}

The results showed that most respondents were female and an average age of 17 years. Authoritarian parenting with a mean value of 34.40 , with a standard value of 5.892 , a minimum value of 19 and a maximum value of 50, with a 95\% confidence level, the lowest value of 33.42 and a high value of 35.38. Stress level with a mean value of 30.04 and a standard deviation value of 6.912, a minimum value of 15 , a maximum value of 47 , with a $95 \%$ confidence level obtained the lowest value of 28.88 and the highest value of 31.19 . Self-price with a mean value of 29.05 , a value of the median is 29.00 , the standard deviation is 3.957 , the minimum value is 20 , the maximum value is 39 , with a $95 \%$ confidence level, the lowest value is 28.39 and the highest value is 29.71 .

The results showed that there was a relation between parents' authoritarian parenting with stress levels in a positive or unidirectional direction, the more often parents applied authoritarian parenting to children, the higher the stress experienced by children. When parents apply authoritarian parenting that is too often for their children will result in children who will easily experience stress disorders, in addition to parenting support from parents and the environment around teenagers is needed right in adolescence so that adolescents get the right coping stress and does not end in mental disorders due to lack of support from the surrounding environment and lack of adolescents in the process of coping with stress correctly. And there is no relation between authoritarian parenting with adolescent self-esteem which has a low interpretation with the direction of a negative relation, believing the higher the parents' authoritarian parenting values, the lower the adolescent self-esteem value, which plays a major role is the social environment of adolescents. So it is expected that parents can provide the support that is always positive in adolescent activities that benefit their lives and can involve various parties in providing guidance to adolescents.

\section{REFERENCES}

1. Ali, M \& Asrori, M. Psikologi Remaja Perkembangan Peserta Didik. Jakarta: Bumi Aksara. (2010)

2. Hashmi S. Adolescence: An Age of Storm and Stress. Review of Arts and Humanities. 2. 1. (2013)

3. Sarwono WS. Psikologi Remaja: Definisi Remaja, Jakarta: Raja Grafindo Persada. (2012).

4. Papalia, dkk. Human Development. Edisi 10. Jakarta. Salemba humanika. (2009)

5. Baron, Robert. A \& Byrne, D. Psikologi Sosial Jilid 2. Jakarta: Erlangga. (2012)

6. Willis, Sofyan S. Remaja dan Masalahnya. Bandung: Alfabeta. (2014).

7. Bhaskar Khobraji W, Jugal K \& Charu K. Prevalence of Stress among School Adolescents in Delhi. Indian Journal of Youth and Adolescent Health. 2. 4, (2015).

8. Gunarsa. Singgih. D Ny. \& Gunarsa, Singgih. D. Psikologi Remaja. Jakarta : Gunung Mulia. (2007)

9. Santrock, Jhon W. Life-span Development ; perkembangan masa hidup. Edisi 5 jilid 2, Jakarta : Erlangga. (2007). 
10. Jadon, Priyansha S \& Tripathi Shraddha. Effect of Authoritarian Parenting style on self esteem of the Child: A Systematic Review. IJARIIE.3.3. (2017)

11. Yusuf, S. Psikologi Perkembangan Anak \& Remaja. Bandung: Remaja Rosdakarya. (2011)

12. Loke Alice Y \& Mak Yim-wah. Family Process and Peer Influences on Substance Use by Adolescents. International Journal of Environmental Research and Public Health.10.38. (2013)

13. Bleidorn W, et al. Age and Gender Differences in Self-Esteem A Cross-Cultural Window. Journal of Personality and Pyschology. 3.3. (2016)

14. Rath S \& Nanda S. Self Concept : A Psychosocial Study on Adolescents. International Journal of Multidisciplinary Research.2.5. (2012).

15. Martinez Isabel \& Garcia Jose F. Impact of Parenting Styles on Adolescents' Self-Esteem and Internalization of Values in Spain. The Spanish Journal of Psychology. 10. 2 (2007)

16. Sharma G \& Pandey N. Parenting Styles and Its Effect on Self-Esteem of Adolescents. The International Journal of Indian Psychology. 3.7. (2015).

17. Santrock. Remaja. Edisi 11 Jilid 2. Jakarta: Erlangga. (2010)

18. Smith C. J. \& O'brien C. J. Occupational Therapy for Children and Adolescents.(7th edition). Canada : Elsevier Mosby. (2015).

19. Widyarini, N. Seri Psikologi Populer: Kunci Pengembangan Diri. Jakarta. PT. Elex Media Komputindo. (2009). 